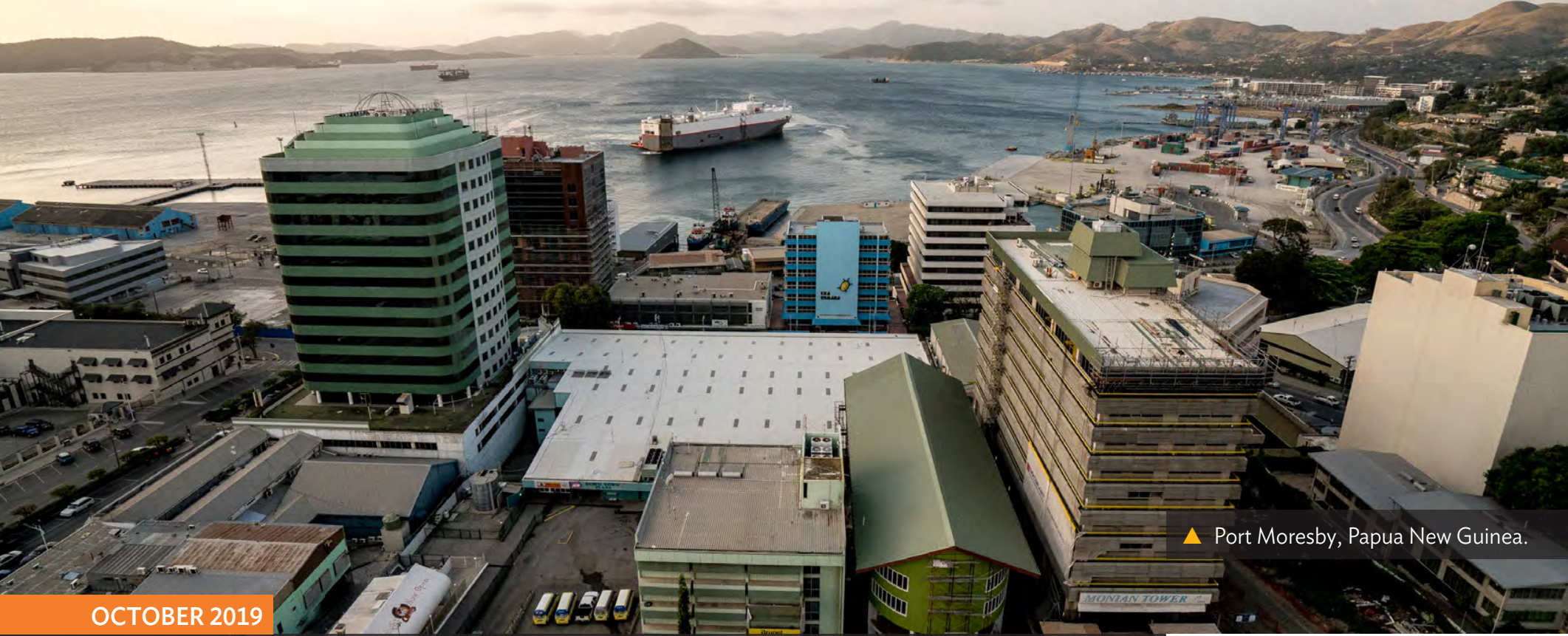

\title{
PACIFIC FINANCE SECTOR BRIEFS
} ADB PACIFIC LIAISON AND COORDINATION OFFICE

PAPUA

NEW GUINEA

AT A GLANCE

\section{PAPUA NEW GUINEA}

The economy of Papua New Guinea (PNG) is dominated by labor-intensive agriculture and capital-intensive extraction of oil, gold, copper, and silver. PNG's formal economy consists of enclave extractive industries (mining, petroleum, and logging); the production of cash crops; and a small, import-substituting manufacturing sector. The informal economy, from which roughly $87 \%$ of PNG's people derive their livelihoods, is largely characterized by subsistence agriculture. Mining and petrochemicals now account for over a quarter of PNG's gross domestic product (GDP) - greater than the combined contribution of agriculture, forestry, and fisheriesand over $80 \%$ of exports. Agriculture, forestry, and fisheries account for $20 \%$ of industry gross value added, while the manufacturing sector remains small and consists of food processing and canning, bottling of soft drinks and beer, tobacco processing, and furniture making.

PNG continues to face significant challenges in making economic growth more broadly based to achieve sustainable and inclusive development outcomes. Available data show that less than $10 \%$ of the country's working age population is able to access formal job opportunities in the private sector. Moreover, many areas of service delivery-such as health, education, transport, energy, and water-remain weak, particularly in rural areas. PNG was unable to meet any of its Millennium Development Goals. For growth to be inclusive and sustainable, PNG needs a more conducive environment for the private sector to expand and create jobs.

\section{FINANCE SECTOR OVERVIEW}

PNG's finance sector is advancing, but it remains limited in scope. The country's ratio of private sector credit to GDP averaged 22\% from 2011-2017. As with some other countries in the region, PNG's economy is only moderately monetized, with its ratio of broad money (M3) to GDP still below 50\% as of 2017 (Table 1).
Population

$8,251,000(2017)^{\mathrm{a}}$

GDP (current \$)

$\$ 25$ billion (2018)

GDP per capita

$\$ 2,773(2018)^{\mathrm{b}}$

GNI per capita

$\$ 2,410(2017)^{a}$

Domestic credit provided by the banking sector (\% of GDP) $44.3 \%(2017)^{\mathrm{a}}$

Financial system assets (\% of GDP) $63.4 \%(2017)^{\mathrm{a}}$

GDP = gross domestic product $\mathrm{GNI}=$ gross national income . Source: Asian Development Bank. 2018. Key Indicators for Asia and the Pacific. Manila.

Source: Asian Development Bank. 
Table 1: Nominal Gross Domestic Product, 2011-2017

\begin{tabular}{lrrrrrrr}
\hline & $\mathbf{2 0 1 1}$ & $\mathbf{2 0 1 2}$ & $\mathbf{2 0 1 3}$ & $\mathbf{2 0 1 4}$ & $\mathbf{2 0 1 5}$ & $\mathbf{2 0 1 6}$ & $\mathbf{2 0 1 7}$ \\
\hline GDP (\$ million) & 18,234 & 21,321 & 21,327 & 23,152 & 22,501 & 21,580 & 23,165 \\
M3 (\$ million) & $6,539.0$ & $8,152.6$ & $8,091.4$ & $7,653.1$ & $7,098.8$ & $7,138.9$ & $6,969.7$ \\
M3/GDP (\%) & 35.9 & 38.2 & 37.9 & 33.1 & 31.5 & 33.1 & 30.1 \\
Private sector credit (\$ million) & $3,815.4$ & $4,873.9$ & $5,348.3$ & $5,264.4$ & $4,909.9$ & $4,583.2$ & $4,410.6$ \\
\hline Private sector credit/GDP (\%) & 20.9 & 22.9 & 25.1 & 22.7 & 21.8 & 21.2 \\
\hline
\end{tabular}

$\mathrm{GDP}=$ gross domestic product, $\mathrm{M} 3$ = broad money .

Note: Figures were converted from kina to United States dollars using the ADB-recognized exchange rates for each year

Sources: Asian Development Bank and Bank of Papua New Guinea.

Weak development and access remain a challenge for the country's finance sector. The International Monetary Fund (IMF) observed in 2015 that the size, composition, breadth, and diversity of PNG's financial services sector were still limited. Only four commercial banks were operating in PNG at the end of 2015. The number of other financial institutions, such as credit unions and cooperatives, did not increase substantially from 2004 to 2015. In 2015, PNG had only seven ATMs for every 100,000 adults, a figure that had not changed in the preceding 5 years. The Asian Development Bank (ADB) noted in 2015 that growth of PNG's finance sector remained limited due to the country's geography and remoteness as well as its high levels of crime, corruption, and poor security restricting cash movements across most of the country. Weak growth of the sector may also be attributed to excessive regulation and high costs (which hinder competition), and limited knowledge of financial services (which restricts business growth).

\section{FINANCE SECTOR STRUCTURE}

PNG's finance sector is more developed than that of ADB's 14 other Pacific developing member countries (DMCs), but it still trails comparable countries in other regions. Unlike most Pacific DMCs, PNG's finance sector not only includes the usual institutions such as commercial banks and microfinance companies, but includes more complex entities such as superannuation funds, life insurance companies, and a stock exchange (Table 2). The Bank of Papua New Guinea serves as the primary government regulator for most financial institutions in PNG. Despite the diversity of institutions, PNG's finance sector remains underdeveloped. Many Papua New Guineans do not have bank accounts and are uninsured. A 2018 World Bank report into financial protection highlighted that a significant portion of lending to individuals is provided by unregulated lenders, often at highly inflated rates of interest. While there is potential for the development of the sector, several constraints hinder its expansion.

PNG's finance sector grew an average of $15 \%$ each year from 2011-2013, but has since declined at an average rate of 3.3\% per year (Table 3 ). The sector's assets accounted for $63.4 \%$ of the country's total output in 2017, down from 89.5\% in 2015.
Table 2: Financial System of Papua New Guinea

\begin{tabular}{lc}
\hline Type of Institution & Number \\
\hline Commercial banks & 4 \\
\hline Other financial institutions & 12 \\
\hline Savings and loan societies & 22 \\
\hline Mobile network operator & 1 \\
Money remittance operator & 1 \\
Money changers & 9 \\
\hline Superannuation funds & 4 \\
Investment managers & 5 \\
\hline Fund administrators & 3 \\
Life insurance companies & 5 \\
Life insurance brokers & 4 \\
Stock exchange & 1 \\
Stockbrokers & 2 \\
\hline Total & 73 \\
\hline
\end{tabular}

Sources: Bank of Papua New Guinea and Port Moresby Stock Exchange.

\section{Commercial banks remain the dominant group in PNG's} finance sector. The four commercial banks operating in PNGtwo of which, Bank South Pacific (BSP) and Kina Bank, are locally based-accounted for almost $63 \%$ of the sector's total assets in 2017. The two foreign-owned banks licensed to operate in PNG are the ANZ Banking Group (as ANZ PNG) and Westpac Bank (as Westpac PNG). Among the four commercial banks, BSP accounts for half the banking system's assets, with ANZ PNG and Westpac PNG sharing the bulk of the remainder (ADB 2015). BSP dominates domestic and regional banking as the largest bank with the widest network of branches and the broadest customer base.

\section{The role of superannuation funds in PNG's financial} landscape cannot be understated, as they remain the only institutions with long-term instruments. The four authorized superannuation funds (Nasfund, Nambawan Super, Defense Force Retirement Benefit Fund, and Aon Master Trust) make up the second largest group in PNG's finance sector, accounting for $26 \%$ of financial system assets in 2017 . PNG law requires pension contributions to be made for all government and private sector employees in firms with more than 15 staff. Continued economic growth and a young population make superannuation funds important for long-term savings in PNG. 
Table 3: Financial System Assets 2011-2017 (\$ million)

\begin{tabular}{lccccccc}
\hline & 2011 & 2012 & 2013 & 2014 & 2015 & 2016 & 2017 \\
\hline Commercial banks & $8,660.5$ & $10,895.8$ & $11,139.8$ & $10,270.1$ & $9,938.3$ & $9,437.2$ & $9,219.5$ \\
Superannuation funds & $2,708.3$ & $3,500.6$ & $3,741.4$ & $3,836.2$ & $3,675.5$ & $3,561.2$ & $3,851.2$ \\
Other financial institutions & 864.2 & $1,011.5$ & $1,083.8$ & $1,035.3$ & 955.0 & 852.5 & 933.7 \\
\hline Insurance companies & 407.8 & 504.7 & 674.4 & 614.7 & 530.1 & 460.9 & 497.4 \\
National development bank & 112.6 & 182.1 & 207.3 & 225.1 & 213.4 & 192.4 \\
Total assets & $12,753.5$ & $16,094.7$ & $16,846.8$ & $15,981.5$ & $15,312.2$ & $14,504.1$ & $14,692.2$ \\
\hline
\end{tabular}

Note: Figures were converted using Asian Development Bank's 2017 exchange rate.

Source: Bank of Papua New Guinea.

Table 4: Consolidated Loans and Advances from Commercial Banks (\$ million)

\begin{tabular}{|c|c|c|c|c|c|c|c|}
\hline & 2011 & 2012 & 2013 & 2014 & 2015 & 2016 & 2017 \\
\hline Agriculture & 69.5 & 105.3 & 105.8 & 107.5 & 90.0 & 60.6 & 63.5 \\
\hline Industry & 494.0 & 809.7 & 840.4 & 909.1 & $1,059.7$ & 905.5 & 656.6 \\
\hline Services & 1,916.1 & $2,403.9$ & $2,611.5$ & $2,890.6$ & $2,613.7$ & $2,677.9$ & $2,571.8$ \\
\hline Finance & 10.0 & 15.4 & 14.8 & 16.5 & 13.0 & 66.6 & 102.0 \\
\hline Total & $2,489.5$ & $3,334.4$ & $3,572.6$ & $3,923.8$ & $3,776.4$ & $3,710.5$ & $3,393.9$ \\
\hline
\end{tabular}

Note: Figures were converted using Asian Development Bank's 2017 exchange rate.

Source: Bank of Papua New Guinea.

These funds may also play an important role in the future development of capital markets and in the government bond market (ADB 2015).

Meanwhile, microfinance institutions provide an alternative source of financial services to the less privileged. With commercial banks focusing more on urban-based transactions, microfinance firms have a growing role in the rural economy. Even urban-based small enterprises that do not have access to formal financial services are being serviced by microfinance firms. These institutions are largely used for savings, since deposits greatly exceed loans, indicating the important role of the microfinance sector in providing liquidity to PNG's financial system (ADB 2015).

\section{COMPOSITION OF CREDIT}

Credit access in PNG has improved over time. Total loans and advances grew considerably from 2011 to 2015, though these have fallen from 2015 to 2017 (Table 4). Among 11 Pacific DMCs, PNG ranked second in the 2017 World Bank Doing Business survey on the ease of getting credit. ${ }^{1}$ PNG strengthened access to credit by passing a law that broadens the scope of assets that can be used as collateral and allows out-of-court enforcement of collateral (World Bank 2017). Such reforms can provide a more conducive environment for growth of small enterprises.
Although there has been an increase in the industry sector's share of commercial bank loans since 2012, the services sector, with $75.7 \%$ of loans, remains the biggest recipient of commercial bank funding.

\section{FINANCE SECTOR PERFORMANCE}

Private sector credit grew steadily from 2011 to 2014 at average of $15.7 \%$ per year. However, from 2015 to 2017 it has declined at an average rate of $8.6 \%$ a year (Table 5 ). Nonperforming loans increased from 2013 to 2015, and have remained elevated. However, the lending rate declined by an average of $4.1 \%$ from 2011 to 2017, indicating some improvements in access to credit.

\section{After strong growth in 2012, the value of bank deposits has} fallen. Bank deposits increased sharply by $22.8 \%$ from 2011 to 2012 , but have since declined at an average rate of $4.9 \%$ per year. This is despite the introduction of financial literacy programs to encourage an inclusive financial system and broaden the depositor base.

The majority of the population still has limited access to finance as banks remain reluctant to lend. Borrowers tend to be urban-based, with banks maintaining low exposure to agriculture and semi-subsistence farming, despite $80 \%$ of PNG's population depending on the agriculture sector.

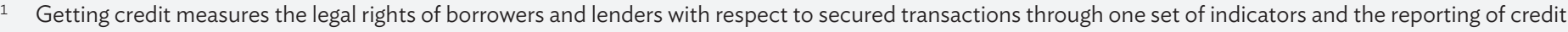
information through another. The first set of indicators measures whether certain features that facilitate lending exist within the applicable collateral and bankruptcy laws. The second set measures the coverage, scope, and accessibility of credit information available through credit-reporting service providers, such as credit bureaus or credit registries (World Bank 2017). 
Table 5: Financial Sector Performance Indicators

\begin{tabular}{lrrrrrrr}
\hline & 2011 & 2012 & 2013 & 2014 & 2015 & 2016 & 2017 \\
\hline NPL ratio (\%) & 2.1 & 2.2 & 1.8 & 2.1 & 3.1 & 2.5 & 2.8 \\
\hline Deposits (\$ million) & $6,924.4$ & $8,505.3$ & $8,435.5$ & $7,966.4$ & $7,391.8$ & $7,144.5$ & $6,620.7$ \\
\hline Commercial bank loans to the private sector (\$ million) & $2,468.9$ & $3,333.6$ & $3,565.6$ & $3,910.4$ & $3,738.6$ & $3,603.1$ & $3,274.7$ \\
\hline Deposit rate (\%) & 0.9 & 0.5 & 0.3 & 0.3 & 0.4 & 0.7 \\
Lending rate (\%) & 10.8 & 10.8 & 10.1 & 9.4 & 8.7 & 8.4 \\
\hline
\end{tabular}

$\mathrm{NPL}=$ nonperforming loans.

Note: Figures were converted using Asian Development Bank's 2017 exchange rate.

Sources: International Monetary Fund and Bank of Papua New Guinea.

Table 6: Financial Access Indicators

\begin{tabular}{lrrrrrrr}
\hline & 2011 & 2012 & 2013 & 2014 & 2015 & 2016 & 2017 \\
\hline Number of bank branches & 75 & 77 & 77 & 77 & 77 & 377 \\
Number of ATMs & 309 & 315 & 351 & 371 & 377 \\
Number of deposit accounts with commercial banks & 762,950 & $1,112,627$ & $1,166,173$ & $1,371,275$ & $1,880,330$ & $2,140,024$ & $2,486,823$ \\
Number of loan accounts with commercial banks & 205,421 & 187,514 & 180,978 & 225,472 & 238,749 & 194,125 & 215,715 \\
\hline
\end{tabular}

Source: International Monetary Fund. 2019. Financial Access Survey. Washington, DC.

Bank loans are normally extended only to large and medium-sized formal sector companies, while smaller firms find it difficult to access credit (ADB 2015). Regulatory barriers and high costs have discouraged the growth of the banking sector.

\section{Meanwhile, insurance companies and other financial} institutions have seen growth in their assets, albeit marginally. Although the assets of these companies grew from 2011 to 2015, the growth was of only slight significance as it did not alter the overall structure of the finance sector. Other financial institutions-including merchant banks, savings and loans societies, investment managers, and fund administratorsrepresented, on average, $6.4 \%$ of the sector from 2011 to 2015 , while insurance companies comprised $3.5 \%$. Insurance makes up a small part of PNG's economy, below $2 \%$ of GDP, compared to a global average of 7.5\% (Oxford Business Group 2016).

Although the country's insurance industry is generally in good health, some companies are not well capitalized, and the collapse of one company could have a significant impact on the finance sector. Weak insurance regulation has led to a lack of transparency and reliable data.

Capital markets remain poorly developed, even though PNG is one of only two Pacific island countries with a stock exchange (the other being Fiji). Founded in 1999, the Port Moresby Stock Exchange has only 15 listed companies, with limited options for investors resulting in a low market capitalization of K54.4 billion. Its rules are used under license from the Australian Stock Exchange, on which some of the Port Moresby Stock Exchangelisted companies are also listed. The industries of the companies listed include aviation, banking, finance, manufacturing, mining, oil, and gas. Difficulties surrounding the availability and movement of foreign currency in recent years has also provided a challenge for some looking to invest in PNG.

\section{FINANCIAL INCLUSION}

Strong progress has been made in modernizing PNG's banking methods, while traditional banking infrastructure has been gradually expanding. As of 2017, there were 77 bank branches in PNG, while the number of ATMs had reached 463. PNG has a relatively high number of mobile banking accounts per adult, compared to other Pacific island countries-9.4\% versus $4 \%$ in Fiji, and none in Vanuatu (IMF 2015).

Despite gains in financial inclusion, PNG still compares poorly against regional averages and other lower middleincome countries for most indicators of financial access. The IMF (2015) cites, for example, that in 2013 only $27 \%$ of adults in PNG held deposit accounts. This compares with an average of $76 \%$ of adults in lower middle-income Asian countries in the same year, and $85 \%$ of adults in developing Asian countries. Moreover, only $4 \%$ of adults in PNG had outstanding credit at the end of 2013 , compared to $17 \%$ of adults in lower middle-income Asian countries and $18 \%$ of adults in developing Asian countries. The latest Financial Development Index of the IMF indicates that, in terms of both finance sector depth and access to financial services, PNG is lagging behind regional averages. This indicates the need for more relevant infrastructure-from better roads and transport services to more ATMs and mobile banking servicesand for intensified financial education and literacy initiatives to deepen the coverage of financial services.

\section{CHALLENGES IN THE FINANCE SECTOR}

The majority of the population of PNG has limited access to formal financial services. Around 63\% of Papua New Guineans do not have any form of banking or financial accounts (Center for 
Excellence in Financial Inclusion and Bank of Papua New Guinea 2016). While structural constraints play a role in limiting financial access, limited knowledge of, or exposure to, financial services, as well as geographical distance from these services, are also major contributors. Lack of access to finance seriously impedes the growth of PNG's private sector. With financial services concentrated mostly in urban areas, increasing the access of rural and remote residents, through financial literacy training and noncash payments or savings, has become a primary focus of government strategies.

Weak financial access and an underdeveloped finance sector is rooted in both economic-level and country-specific factors. Stringent regulations are potential barriers to a competitive banking industry and broader deposit base for PNG. Compliance with regulations related to customer registration and monitoring, for example, has led to increasing documentary requirements that have increased compliance costs, discouraged existing customers from opening new accounts, and deterred potential customers from accessing the formal financial system. Meanwhile, the low level of urbanization in PNG is a serious hurdle to financial access and information, making financial literacy programs all the more important.

\section{Although PNG's banking system is highly liquid, sound, and profitable, its finance sector remains shallow due to structural constraints. The IMF (2017) noted that return on assets was around 2\% (as of June 2016) and had averaged a healthy $2.5 \%$ since 2006 , and that the capital adequacy ratio was high (at $32.3 \%$ as of June 2016). The ratio of nonperforming and past-due loans to total risk-weighted assets was around $6 \%$ in June 2016, above the stable 10-year average of around 5\%. Despite this, banks only hold around half of their assets as loans, with the other half held largely as short-term securities and cash. This scenario is due to structural constraints such as law and order, contract enforceability, property rights, and land tenure. These are key constraints that increase credit risk and will take time to address.}

The government has taken steps to reform PNG's finance sector and make it more inclusive. It has made the strengthening of bank governance a top priority. The government also increased worker participation in superannuation funds by lowering from 15 to 10 the number of people employed in order for an enterprise to be required to participate. The government also aims to promote and expand financial literacy, broaden insurance coverage, create a financial consumer protection system, provide financial services to informal and agricultural enterprises, enhance financial access for small and medium-sized enterprises, and promote the expansion of digital financial services.

\section{REFERENCES}

Asian Development Bank (ADB) and Asian Development Bank Institute. 2015. Pacific Opportunities: Leveraging Asia's Growth. Manila.

ADB. 2015. Building a Dynamic Pacific Economy-Strengthening the Private Sector in Papua New Guinea. Manila.

Bank of Papua New Guinea website. https://www.bankpng.gov.pg.

Center for Excellence in Financial Inclusion and Bank of Papua New Guinea. 2016. Second National Financial Inclusion Strategy. http://www.pfip.org/wp-content/ uploads/2017/01/2-PNG-NATIONAL-FINANCIALINCLUSION-STRATEGY-2016-2020-final.pdf (accessed 19 June 2019).

International Monetary Fund (IMF). 2015. Papua New Guinea: selected issues. IMF Country Report. No. 15/319. Washington, DC

2017. Papua New Guinea: 2016 Article IV consultation. IMF Country Report. No. 17/22. Washington, DC.

_ 2019. Financial Access Survey. Washington, DC. Online portal. http://data.imf.org/?sk=E5DCAB7E-A5CA-4892A6EA-598B5463A34C (accessed 19 June 2019).

Oxford Business Group. 2016. The Report: Papua New Guinea 2016. London.

World Bank. 2017. Doing Business 2017: Equal Opportunity For All. Washington

2018. Papua New Guinea Financial Consumer Protection Diagnostic 2018.

\section{About the Asian Development Bank}

ADB is committed to achieving a prosperous, inclusive, resilient, and sustainable Asia and the Pacific, while sustaining its efforts to eradicate extreme poverty. Established in 1966, it is owned by 68 members49 from the region. Its main instruments for helping its developing member countries are policy dialogue, loans, equity investments, guarantees, grants, and technical assistance.

This Finance Sector Brief was prepared by ADB's Pacific Department.

The views expressed in this publication are those of the authors and do not necessarily reflect the views and policies of ADB or its Board of Governors or the governments they represent.
Asian Development Bank

Pacific Liaison and Coordination Office

Level 20, 45 Clarence St, Sydney, 2000, Australia

+61282709429

https://www.adb.org/publications/pacific-finance-sector-png

Corrigenda to ADB publications may be found at http://www.adb.org/publications/corrigenda

In this publication, “\$” refers to US dollars.

All photos are from $A D B$. 